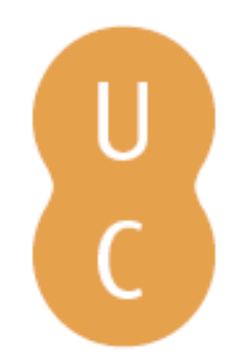

\title{
nombalina
}

\section{La tragedia de las mujeres troyanas en las Metamorfosis de Ovidio}

Autor(es): $\quad$ Iglesias, María; Álvarez-Rosa, María Consuelo

Publicado por: Imprensa da Universidade de Coimbra

URL

persistente: URI:http://hdl.handle.net/10316.2/32807

DOI: $\quad$ DOI:http://dx.doi.org/10.14195/978-989-26-0236-3_5

Accessed : $\quad$ 26-Apr-2023 09:27:25

A navegação consulta e descarregamento dos títulos inseridos nas Bibliotecas Digitais UC Digitalis, UC Pombalina e UC Impactum, pressupõem a aceitação plena e sem reservas dos Termos e Condições de Uso destas Bibliotecas Digitais, disponíveis em https://digitalis.uc.pt/pt-pt/termos.

Conforme exposto nos referidos Termos e Condições de Uso, o descarregamento de títulos de acesso restrito requer uma licença válida de autorização devendo o utilizador aceder ao(s) documento(s) a partir de um endereço de IP da instituição detentora da supramencionada licença.

Ao utilizador é apenas permitido o descarregamento para uso pessoal, pelo que o emprego do(s) título(s) descarregado(s) para outro fim, designadamente comercial, carece de autorização do respetivo autor ou editor da obra.

Na medida em que todas as obras da UC Digitalis se encontram protegidas pelo Código do Direito de Autor e Direitos Conexos e demais legislação aplicável, toda a cópia, parcial ou total, deste documento, nos casos em que é legalmente admitida, deverá conter ou fazer-se acompanhar por este aviso. 
Carmen Soares

Maria do Céu Fialho

María Consuelo Alvarez Morán

Rosa María Iglesias Montiel

Coordenação

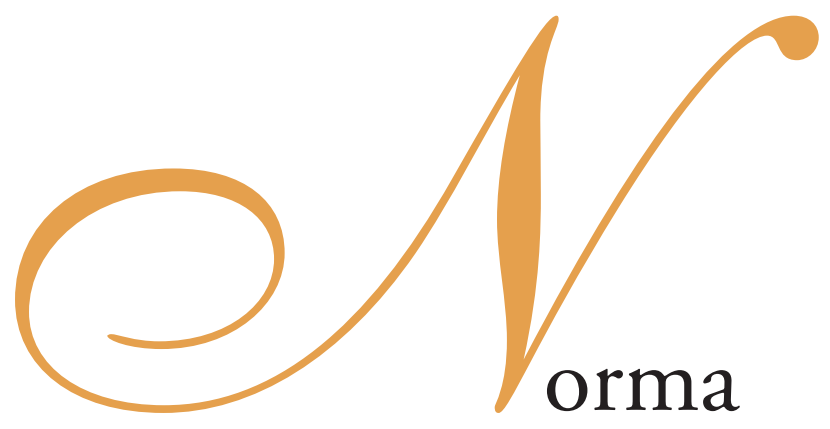

\& Transgressão

II

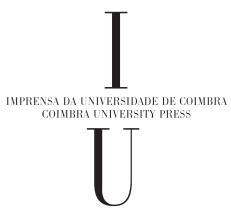




\author{
Carmen Soares \\ Maria do Céu Fialho \\ María Consuelo Alvarez Morán \\ Rosa María Iglesias Montiel \\ Coordenação
}

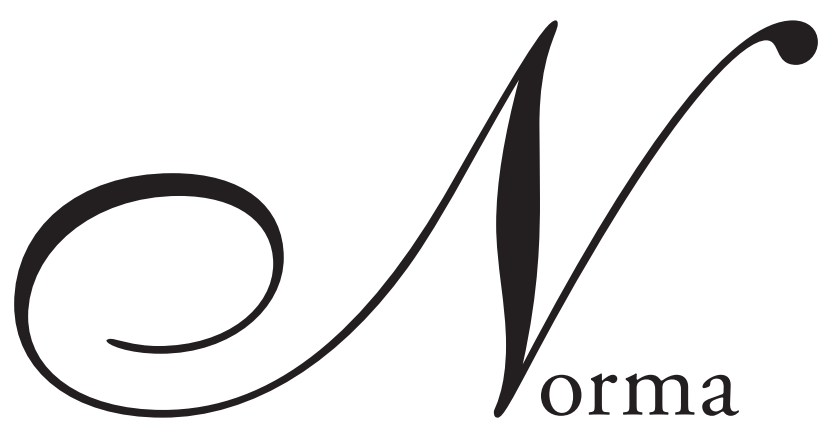

\& Transgressão

II

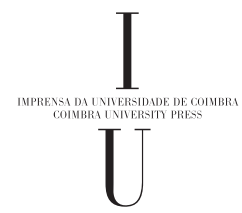




\title{
COORDENAÇÃo EDITORIAL
}

Imprensa da Universidade de Coimbra

Email: imprensauc@ci.uc.pt

URL: http://www.uc.pt/imprensa_uc

Vendas Online: http://www.livrariadaimprensa.com

\author{
CONCEPÇÃO GRÁFICA \\ António Barros \\ INFOGRAFIA \\ Carlos Costa \\ Imprensa da Universidade de Coimbra
}

EXECUÇÃO GRÁFICA

Europress

ISBN

978-989-26-0105-2

Depósito LEgal

OBRA PUBlicada COM O APOIO de:

Centro de Estudos Clássicos e Humanísticos

Faculdade de Letras da Universidade de Coimbra

FCT Fundação para a Ciência e a Tecnologia

MINISTÉrio DA CIÊNCCA, TECNOLOGIA E ENSINO SUPERTOR Porugal

Programa Operacional Ciência e Inovação 2010 


\section{CAPítulo II}

Os ClásSicos e a SUA RECEPÇÃo: CONTRIBUTOS PARA A (DES)CONSTRUÇÃO DE IDENTIDADES CULTURAIS 
2.1. Literatura LATINA 
María Consuelo Álvarez-Rosa María Iglesias

Universidad de Murcia

\section{LA TRAGEDIA DE LAS MUJERES TROYANAS EN LAS METAMORFOSIS DE OVIDIO ${ }^{1}$}

Los relatos sobre Troya hasta la muerte de Aquiles del libro XII de las Metamorfosis tienen como fundamental hipotexto la epopeya, sea la Ilíada homérica sea el Ciclo épico; en cambio el libro XIII se inicia con el armorum iudicium, que, aunque ya mencionado en la Odisea y en la Etiópide, es un argumento básicamente de tragedia a la vez que era tema preferido en los ejercicios de las escuelas de retórica. Ovidio tamiza ambos tratamientos, especialmente el retórico, pero aprovecha que Ulises es el vencedor del litigio para, mediante el término victor (13. 399), efectuar la transición cronológica al viaje de Ulises a Lemnos, con lo que nos da claros indicios de estar siguiendo el Filoctetes de Sófocles, es decir que ha tomado partido por la tragedia en detrimento de la Ilias parva en la que es Diomedes el encargado de traer las armas de Hércules. No parece interesado Ovidio en concederle mayor protagonismo al de Ítaca, pues silencia otros dos grandes sucesos situados cronológicamente entre la vuelta de Lemnos y la definitiva caída de Troya: el robo del Paladio y la estratagema del caballo, en los que fueron determinantes la actuación y el ingenio de Ulises. La ausencia del astuto y despiadado Laertíada es una constante en la reescritura del drama

\footnotetext{
${ }^{1}$ Este trabajo se ha redactado al amparo del Proyecto FFI2008-03346, subvencionado por el MICINN, y es resultado del PI 08846/PHCS/08, financiado con cargo al Programa de Generación de Conocimiento Científico de Excelencia de la Fundación Séneca-Agencia de Ciencia y Tecnología de la Región de Murcia en el marco del II PCTRM 2007-10.
} 
de las troyanas, pues no hace Ovidio mención alguna de cómo convenció a los aqueos para dar muerte a Astianacte y Políxena, maniobra que Eurípides pone en boca de Taltibio en Troyanas (721-725) y se rememora en la Hécuba tanto en los lamentos del coro (130-145) como en el agón entre la otrora reina de Troya y el propio Ulises (218-331), en el que Hécuba fundamenta su argumentación para intentar salvar a su hija en razones políticas, que poco interesan a Ovidio. Es más, se apresura el sulmonés en adelantar el cierre del episodio, pues sólo la metamorfosis de Hécuba justifica la inclusión de todo el relato en este epos sobre cambios de forma, detalle que únicamente tiene que ver con el final de la Hécuba euripídea. Sirve de transición, pues, al relato sobre las desgracias de las mujeres troyanas un resumen del drama, lo que podríamos considerar una auténtica bypothesis, en Met. 13. 404-407:

Troia simul Priamusque cadunt, Priameia coniunx

perdidit infelix hominis post omnia formam

externasque novo latratu terruit auras,

longus in angustum qua clauditur Hellespontus.

"Troya y a la vez Príamo caen, la desgraciada esposa de Príamo perdió, después de todas las cosas, la figura humana y, con un inaudito ladrido, llenó de terror los extranjeros aires, por donde el alargado Helesponto se cierra en una estrechura." ${ }^{2}$

Como tantos otros a lo largo del poema, estos versos cumplen en nuestra opinión ${ }^{3}$ la importante función de recordar una metamorfosis, introduciendo el episodio que sirve de aition a tal cambio de forma, con el que concluirá el relato. Ovidio proporciona claros indicios de que va a seguir la Hécuba de Eurípides, primer autor, como sabemos, que habla de la transformación de Hécuba en perra. Pero no lo hará de forma inmediata, sino que, hasta llegar a los acontecimientos contenidos en esa tragedia, en lugar de ceñirse a un solo modelo, que bien podían ser las Troyanas, va entrelazando los

\footnotetext{
2 Todas las traducciones de las Metamorfosis son de Álvarez-Iglesias 2009, 9ª ed..

3 Debido a su importancia estructural, no dudamos de la autenticidad de estos versos, que ha sido puesta en duda en varias ocasiones, para lo cual cf. F. Bömer 1982: 299.
} 
datos extraídos de los dramas con los procedentes de epopeyas. Así, a partir del v. 408 se inicia el relato de las desgracias de las cautivas dardanias, en una aparente adaptación de Troyanas, pues Met. 13. 409-410:

exiguumque senis Priami Iovis ara cruorem

conbiberat.

"Y el altar de Júpiter había embebido la escasa sangre del anciano Príamo".

bien puede ser leído como un eco de Tr. 16-17 en que se menciona el asesinato de Príamo:

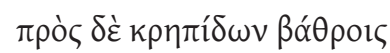

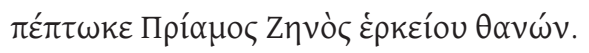

"Al pie de las gradas del altar de Zeus protector del hogar ha caído muerto Príamo"

pero parece más bien que Ovidio no quiere extenderse en un episodio muy conocido por sus lectores y que ya había sido objeto de un pormenorizado desarrollo en Verg. Aen. 2. 506-5584, como tantas veces hace obviando lo que ya tratara Virgilio5.

Por otra parte, la descripción de la afrenta sufrida por Casandra de Met. 13. 410-411:

tractisque comis antistita Phoebi

non profecturas tendebat ad aethera palmas.

"Y arrastrada por los cabellos la sacerdotisa de Febo tendía hacia al cielo unas palmas que de nada le iban a servir"

4 Para los resúmenes del libro segundo de la Eneida y comienzos del tercero, cf. S. Döpp 1968: 130-131.

5 Sobre las diferentes técnicas de cómo Ovidio utiliza a Virgilio, véase R. Ma Iglesias-M ${ }^{a}$ C. Álvarez 2004 y M Málvarez Morán -R. Ma Iglesias Montiel 2009. Cf. también M ${ }^{\mathrm{a}} \mathrm{C}$ Álvarez Morán -R. Ma Iglesias Montiel 2005. 
no es reminiscencia de la escueta respuesta de Posidón ${ }^{6}$ a Atenea en Tr. 70 sino indudable adaptación de Virgilio Aen. 2. 402-406:

Ecce trabebatur passis Priameia virgo crinibus a templo Cassandra adytisque Minervae, ad caelum tendens ardentia lumina frustra, lumina, nam teneras arcebant vincula palmas.

"He aquí que es arrastrada por los cabellos en desorden Casandra, la doncella hija de Príamo, fuera del templo y de los santuarios de Minerva, tendiendo en vanos sus ardientes ojos al cielo, los ojos pues las ataduras encadenaban sus delicadas manos".

versos que le han servido además de intermediarios con la Iliupersis, tanto en la alusión a la muerte de Príamo (Allen V 107, 30-31) como en lo concerniente a la deshonrosa actuación de Áyax Oileo (Allen V 108, 2-3).

Ovidio, ajustándose a la norma épica, tiene también muy presente Aen. 2. 489-490 donde se describe la actitud de las mujeres dentro del palacio en los primeros momentos del fin de Troya, cuando los griegos entran a saquear y van en busca de Príamo para darle muerte:

tum pauidae tectis matres ingentibus errant

amplexaeque tenent postis atque oscula figunt.

"Entonces las madres vagan aterrorizadas por la gran mansión y sujetan con su abrazo los postigos y clavan en ellos sus besos".

pues con gran similitud léxica leemos en Met. 13. 412-413:

Dardanidas matres patriorum signa deorum, dum licet, amplexas succensaque templa tenentes.

"A las madres dardanias, que abrazaban las estatuas de los dioses patrios mientras les estaba permitido y ocupaban los templos incendiados".

\footnotetext{
${ }^{6}$ En Troyanas el dios del mar (vv. 41-44), Taltibio en su respuesta a Hécuba (247-252) y la propia Casandra en su presencia en escena (vv. 308-461) hacen hincapié tan sólo en la condición de esclava y concubina de Agamenón.
} 
si bien el momento es diferente: ya ha muerto Príamo, ya están siendo arrebatadas por los griegos, por lo que es mucho más intenso todavía el patetismo de esos brazos adheridos a las puertas y altares de los templos de las aterradas troyanas. Sin embargo, el verso 414 con el que Ovidio culmina la frase:

invidiosa trahunt victores praemia Grai.

"Las arrastraban los griegos vencedores como un galardón que provocaba envidia".

constituye una sutil referencia a que las cautivas no asignadas directamente a un dueño han sido sorteadas entre los griegos, un sorteo que había sido descrito pormenorizadamente por Taltibio en $\operatorname{Tr} .235$ ss., pero al que se aludía tanto en el prólogo por boca de Posidón en Tr. 28-29:

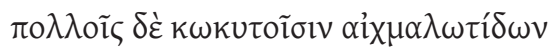
ßоа̃ $\Sigma \kappa \alpha ́ \mu \alpha \nu \delta \rho \circ \varsigma \delta \varepsilon \sigma \pi o ́ \tau \alpha \varsigma ~ \kappa \lambda \eta \rho о u \mu \varepsilon ́ v \omega v$.

"Con los numerosos lamentos de las cautivas sometidas por sorteo a sus amos, resuena el Escamandro".

cuyo despótas está recogido por el victores ovidiano, como en las palabras de Hécuba de 143-145:

\section{$\dot{\alpha} \lambda \lambda^{\prime} \tilde{\omega} \tau \tilde{\omega} \nu \chi \alpha \lambda \kappa \varepsilon \gamma \chi \varepsilon \dot{\varepsilon} \omega \nu$ T $\rho \omega ́ \omega \nu$

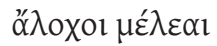

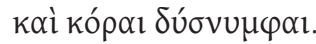

"Ea, joh tristes esposas de los troyanos de broncíneas lanzas y desgraciadas muchachas!"

Además, la inmediata referencia por parte de Ovidio a la muerte de Astianacte sugiere que ya ha habido sorteo, es decir que en este concreto lugar sí se está siguiendo la sucesión de los hechos de Troyanas, donde el anuncio de la decisión de dar muerte al hijo de Héctor se la comunica 
Taltibio a Andrómaca, cuando ya se conoce a quién ha sido asignada cada una de las mujeres nobles de la casa real dardania (Tr. 709 ss.).

Aunque todas las noticias sobre Astianacte en la Literatura Griega dejen traslucir una gran simpatía de los autores hacía el niño, lo que provoca la empatía del lector, es muy probable que fuera Acio en su Astianacte el que describiera con todo detalle la escena que Ovidio vívidamente narra; no obstante, el sentimiento con el que el sulmonés trata la muerte del niño y la ternura que emana de sus palabras al narrar cómo ha sido lanzado de las mismas murallas en las que su madre le mostraba a Héctor, en los vv. 415-417:

mittitur Astyanax illis de turribus, unde

pugnantem pro se proavitaque regna tuentem

saepe videre patrem monstratum a matre solebat.

"Es arrojado Astianacte desde aquellas almenas desde donde muy a menudo solía contemplar a su padre, que le era mostrado por su madre, mientras luchaba en su defensa y protegía el reino de sus antepasados."

no tienen su modelo en las obras conservadas, pues la muerte del niño es presentida por su madre Andrómaca en Il. 24. 734-735, se cuenta en Iliupersis (Allen V 108, 8-9), se describe en Eur. Andr. 9-11, pero en todos estos lugares tan sólo se incide, con mayor o menor extensión, en la lamentable situación de la ausencia de su padre para protegerlo o que con su muerte se pierde toda esperanza de supervivencia para Troya. En cambio, Ovidio hace que se centre la atención en su madre para así sutilmente conseguir que Andrómaca pendiente de su hijo prefigure a Hécuba, la madre que también va a ser privada de la descendencia que aún le vive.

Seguidamente, como transición, recuerda el sulmonés de qué manera las dardanias se alejan de Troya, es decir rememora los versos finales de Troyanas (1287 ss.) en que Hécuba y el coro lamentan la visión de la asolada patria cuando se dirigen a las naves. Así leemos en Met. 13. 420-421: 
'Troia, vale! rapimur' clamant; dant oscula terrae

Troades et patriae fumantia tecta relinquunt.

"¡Adiós Troya! Somos raptadas" gritan; las troyanas dan besos a la tierra y abandonan los humeantes palacios de su patria”.

Coincidimos con F. Bömer en que cuando Ovidio escribe ultima conscendit classem ... / Hecube (Met. 13. 422-423) no se debe a que la reina por su rango cierre el grupo de las mujeres sino que se trata de una concesión a un planteamiento poético; tampoco es una deuda con el drama griego porque así ocurriera en la tragedia eurípidea, donde no se especifica si el coro sigue o antecede a la reina.

La cláusula parentética del v. 422: miserabile visu, nos hace pensar que no sólo mostraría la conmiseración del autor ante el terrible destino de la soberana que sube a una nave como esclava, sino que igualmente serviría para evocar en los lectores la escena del final de Troyanas de Eurípides que tan bien conocían. Pero que tal cláusula, que sólo aparece en este lugar en el epos ovidiano, sea imitación directa de la también única vez que se utiliza en la Eneida (Aen. 1. 111) tiene una relevancia que debe ser destacada, ya que, para dar coherencia al relato, Ovidio crea un insuperable intertexto que sin duda evoca la tormenta provocada por los vientos liberados por Eolo a ruegos de Juno, pero sobre todo sirve para anunciar que las naves a las que suben las cautivas van a sufrir unos infortunios similares a los que en la obra virgiliana padecen los enéadas y que, como en la epopeya, se deben al deseo de venganza de una divinidad, Juno en la Eneida y Atenea en Troyanas, pues en los vv. 65-94 del drama euripídeo la diosa, ofendida por la afrenta a sus altares, ha pedido a Posidón un mar embravecido para obstaculizar el regreso de los aqueos, que portan consigo a las cautivas troyanas.

En esa mezcla continua de forma épica y fondo de tragedia, el poeta tiene in mente tanto el comienzo como el final de Troyanas, donde aparece Hécuba postrada por el dolor que le produce el recuerdo de sus hijos, en especial a partir del v. 1284 en que es arrastrada por los soldados de Ulises. Tal situación la recoge Ovidio precisamente en ese llevársela por la fuerza 
de Met. 13. 425; pero en los versos anteriores ha transcendido la tragedia haciendo que se encuentre a la madre en medio de sus hijos muertos y llevando a cabo una acción que no se menciona en ninguna otra obra, como se ve en 423-426:

in medis Hecube natorum inventa sepulcris:

prensantem tumulos atque ossibus oscula dantem

Dulichiae traxere manus tamen unius hausit

inque sinu cineres se cum tulit Hectoris haustos.

"Hécuba encontrada en medio de los sepulcros de sus hijos; a la que estrechaba los túmulos y daba besos a sus huesos la arrastraron manos duliquias pero al menos de uno sacó las cenizas y en su seno se llevó consigo las de Héctor, que eran las que había sacado".

Madre ante todo se convierte en la urna funeraria de Héctor; tal parece que esta actitud de la anciana en el épico romano intenta ser consecuencia y contrapunto a la vez de una situación que ella misma ha provocado en la tragedia euripídea, cuando en el diálogo esticomítico con Andrómaca de Tr. 577 y ss. ha aconsejado a su nuera que olvide a su marido muerto y se dedique a cumplir con los deberes de esposa para con el que le ha sido asignado por sus captores; es decir que, a fin de que Héctor no sea olvidado, ella, su madre, lo lleva consigo como si quisiera asegurar el imperecedero recuerdo de su hijo, haciéndolo regresar a sus entrañas. No obstante, Ovidio pone término a sus "Troyanas" añadiendo al relato un rasgo de romanidad, pues a los cabellos depositados en las exequias griegas en el momento en que los cadáveres arden en la pira, contrapone un único cabello que responde al ritual romano de su época, 427-428:

Hectoris in tumulo canum de vertice crinem, inferias inopes, crinem lacrimasque reliqui.

"En el túmulo de Héctor dejó un cabello cano de su cabeza, vana ofrenda funeraria, un cabello y sus lágrimas". 
De esta última escena de las "Troyanas" de Ovidio se deduce que el poeta pretende configurar a Hécuba como una gran heroína de epopeya, dándole un papel mucho más relevante que el que tiene en la épica griega y romana que se nos ha conservado. En la Ilíada es una pálida figura cuyo nombre ni siquiera pronuncia Príamo cuando habla de los 19 hijos habidos de una sola mujer (24. 496), una esposa en exceso prudente que quiere disuadir a su marido de acudir al campamento aqueo a reclamar el cuerpo de Héctor (24. 201-216), actitud prudente también resaltada por Virgilio cuando la reina convence a Príamo de que ya es inútil salir a guerrear con Troya ya vencida (Aen. 2. 518-524); una pálida figura que adquiere cierta luz en la Ilíada sólo cuando actúa como madre de Héctor que, discreta, está pendiente de los deseos y necesidades de su hijo (6. 254-262), que le ruega no se enfrente a Aquiles (22. 82-89), una madre que encabeza los lamentos ante el cadáver arrastrado por el carro de su asesino (22. 431-436) y que finalmente llora desgarrada ante su cuerpo rescatado (24. 748-759).

Ovidio se vale de esa configuración épica de madre de Héctor para, con la descripción de un gesto más osado que prudente (inque sinu cineres se cum tulit Hectoris haustos: "y en su seno se llevó consigo las cenizas de Héctor, que eran las que había sacado”), dar paso a un relato épico basado en la Hécuba de Eurípides, en el que la reina ya no es sólo la entristecida anciana que llora su desgraciada situación sino que va a tomar una serie de iniciativas no esperables en la esposa y madre homérica. Además, el sulmonés convertirá a su heroína en la, podríamos decir, una ánax gynaikón, dado que en la adaptación épica de las tragedias euripídeas prescinde, como hemos dicho, no sólo de Ulises sino también de Agamenón, del mensajero Taltibio y de todos los personajes masculinos que no son necesarios para el desarrollo de la acción narrada, lo que constituye una transgresión de la norma pues el papel fundamental de los hombres en la tragedia es anulado por la actuación de las féminas.

Los vv. 429-438, que corresponden al inicio de Hécuba: 
Est, ubi Troia fuit, Phrygiae contraria tellus

Bistoniis habitata viris: Polymestoris illic

regia dives erat, cui te commisit alendum

clam, Polydore, pater Phrygisque removit ab armis,

consilium sapiens, sceleris nisi praemia magnas

adiecisset opes, animi inritamen avari.

ut cecidit fortuna Phrygum, capit inpius ensem

rex Thracum iuguloque sui demisit alumni

et, tamquam tolli cum corpore crimina possent,

exanimem scopulo subiectas misit in undas.

"Hay enfrente de Frigia, donde estuvo Troya, una tierra habitada por hombres bistonios; allí estaba el rico palacio de Poliméstor, a quien te confió para que te criara a escondidas, Polidoro, tu padre y te apartó de la lucha frigia, sabio por su decisión, si no hubiese añadido como pago de un crimen grandes riquezas, acicate para un espíritu avaro. Cuando se vino abajo la suerte de los frigios, toma sin piedad la espada el rey de los tracios y la hundió en la garganta de su pupilo y, como si los crímenes pudieran ser eliminados junto con el cuerpo, arrojó al muerto a las aguas que se extendían bajo un acantilado".

tienen la función estructural de bisagra comúnmente utilizada por Ovidio para dotar de unidad y coherencia a los relatos ${ }^{7}$, bien entendido que cuenta para ello con la complicidad del lector, pues sólo quien conociera la obra del trágico ateniense podría comprender que estos versos son la causa de la actuación de la Hécuba vengadora, que tiene su anticipo en los vv. 404407 de este mismo libro, que hemos definido como bypothesis del drama. Desde el verso 429 hasta el final del episodio (575), Ovidio va a seguir el mismo orden y disposición de los acontecimientos que en la Hécuba: se informa al lector/espectador de la muerte de Polidoro, tiene lugar el sacrificio de Políxena, se relata cómo Poliméstor ha dado muerte a Polidoro y el modo en que Hécuba toma cumplida venganza sobre el traidor rey de Tracia, con lo que la tragedia es el fundamental hipotexto para el de Sulmona, ya que Eurípides es el primero en unir los episodios de Políxena y Polidoro.

7 Se podría incluir entre las "Klammern" analizadas por W. Ludwig 1965, tan alabadas por F.W. Lenz 1967: 497. Para O. S. Due 1974: 155, se trata de una simple transición. 
El deseo de transponer la tragedia a código épico le hace mantener el orden cronológico de los sucesos y por eso no ha mencionado la muerte de Políxena en los versos resumen de los sufrimientos de las cautivas, por más que en Troyanas se hable en varias ocasiones del triste destino de la joven Priámida. Recordemos que Posidón, ya en el prólogo en los vv. 39-40, lo incluye como uno de los motivos del abatimiento de Hécuba:

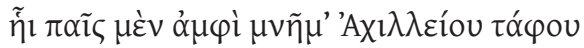

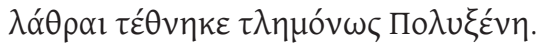

"Su hija Políxena ha muerto con gran valor, a sus espaldas, en el túmulo funerario de Aquiles".

Y recordemos igualmente que en los vv. 260-271 a Hécuba, que pregunta por su hija, Taltibio le da respuestas ambiguas y, entre ellas, en el v. 264 le dice:

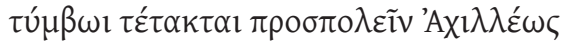

"Le ha sido ordenado servir a la tumba de Aquiles".

También Andrómaca en los vv. 622-623 la informa con total claridad:

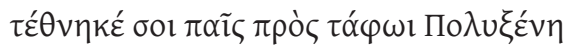

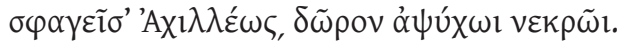

"Ha muerto tu hija Políxena degollada ante la tumba de Aquiles, como don para un cadáver sin alma”.

Y un poco más adelante (vv. 679-683) de nuevo la viuda de Héctor considera preferible la suerte de Políxena que el destino que a ella le aguarda. El silencio por parte de Ovidio, a nuestro parecer, se debe a su decisión de no incurrir en la incoherencia que supone que Eurípides, que había tratado ya la muerte de Políxena antes de la partida de la patria en las Troyanas, la haya hecho salir a escena en Hécuba en la primera escala del viaje, lo que tal vez despertaría los comentarios de los espectadores de época augústea, al asistir a la representación de las dos tragedias 
seguidas sin percatarse de que entre la composición de éstas mediaban 9 años y que la intención del trágico no era la de armonizar para nada los diferentes elementos de la saga, sino que en Hécuba del 424 a. C. había innovado situando la acción después de la salida de la Tróade y sin embargo en Troyanas en el 415 a. C. había dado forma trágica a los datos que encontraba en la épica antigua, pues ya los Cypria (Allen V 125, 2426), según sabemos por Schol. Hec. 41, contaban que Políxena había sido herida mortalmente por Ulises y Diomedes y enterrada por Neoptólemo en la misma toma de la ciudad, e Íbico (Fr. 36), según el mismo escolio, ya decía que había sido sacrificada por Neoptólemo, coincidiendo en esto con la Iliupersis.

Ovidio, que como Virgilio ha leído atentamente la Hécuba de Eurípides, adapta a la narratio épica las palabras del prólogo pronunciadas por el espectro de Polidoro y sustituye el parlamento trágico por la interpelación directa al joven Priámida mediante la apóstrofe de 13. 433-434:

cui te commisit alendum

clam, Polydore, pater Phrygiisque removit ab armis.

"A quien te confió para que te criara a escondidas, Polidoro, tu padre y te apartó de la lucha frigia”.

Utiliza, por tanto, el procedimiento narrativo que en otro lugar nosotras denomináramos ${ }^{8}$ "apóstrofes prolépticas"; un procedimiento con el que mediante el llamativo cambio de marcas gramaticales transpone al relato lineal el patetismo de la tragedia, en la que el espectro del propio joven narra sus desventuras, pero que le sirve además para anunciar que han de sobrevenir desgracias aún mayores.

Ovidio no menciona a Hécuba en este momento no porque Virgilio no hable de ella en el pasaje del libro tercero de la Eneida, donde Eneas rememora el asesinato de Polidoro, sino porque quiere que sus lectores, al igual que el público que asistía a las representaciones de la tragedia eurípidea, sean

\footnotetext{
8 Cf. Ma C. Álvarez-R. Ma Iglesias 2000: 88-89.
} 
informados de la desgracia del Priámida y a la vez sean conscientes de que la madre la ignora. Sí quiere en cambio que se trasluzca su lectura de Virgilio y así, con la fórmula ubi Troia fuit (13. 429), recuerda que en Aen. 3. 11 Eneas expresa los mismos sentimientos que las troyanas al partir de la Troya asolada; sin embargo, esa fórmula es utilizada por Ovidio para corregir al vate de Mantua, porque, cuando Virgilio habla en 3. 13-14 del lugar donde le sobreviene la desgracia a Polidoro, dice que son tierras lejanas:

\section{Terra procul uastis colitur Mauortia campis}

Thraces arant acri quondam regnata Lycurgo.

"Lejos está habitada una tierra, consagrada a Marte, de amplias llanuras, (la aran los tracios) en otro tiempo bajo el reinado del cruel Licurgo"

mientras que el sulmonés recuerda que la rica llanura de la Quersoneso de la que habla el espectro del muchacho en Hec. 8 ("Que estos riquísimos llanos de la Quersoneso cultiva”) está enfrente (contraria y no lejos, el procul virgiliano) de donde estuvo Troya, 13. 429-430:

\section{Est, ubi Troia fuit, Phrygiae contraria tellus}

\section{Bistoniis habitata viris}

"Hay enfrente de Frigia, donde estuvo Troya, una tierra habitada por hombres bistonios".

justamente, como ha precisado en 13. 407, longus in angustum qua clauditur Hellespontus: "por donde el alargado Helesponto se cierra en una estrechura".

Indiferente es si en las Metamorfosis proceden directamente de la tragedia o del epos virgiliano las razones que llevaron a Príamo a buscar la seguridad de su hijo, pero el motivo que mueve a Poliméstor a darle muerte, la avaricia, más que ser adaptación de las palabras de Polidoro en Hec. 25-27:

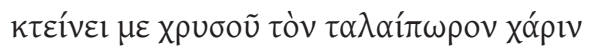

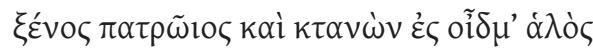

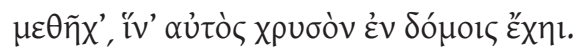


"Me dio muerte a mí, desgraciado, a causa de mi oro, el húesped de mi padre y tras asesinarme me arrojó al hinchado mar para mantener el oro en su morada".

son eco evidente de la exclamación virgiliana en 3. 56-57:

quid non mortalia pectora cogis, auri sacra fames!

"¡A qué no obligas a los mortales pechos, funesta hambre de oro!"

como demuestran los versos ovidianos, Met. 13. 433-434:

consilium sapiens, sceleris nisi praemia magnas

adiecisset opes, animi inritamen avari.

"Sabio por su decisión, si no hubiese añadido como pago de un crimen grandes riquezas, acicate para un espíritu avaro".

Digno de atención por su relevancia es el escenario en el que se desarrollan los sucesos. Los versos de Met. 13. 439-448, en los que el poeta explica las razones de la detención en la costa de Tracia:

Litore Threicio classem religarat Atrides,

dum mare pacatum, dum ventus amicior esset:

bic subito, quantus, cum viveret, esse solebat,

exit humo late rupta similisque minanti

temporis illius vultum referebat Achilles,

quo ferus iniustum petiit Agamemnona ferro

'inmemores'que 'mei disceditis, ' inquit 'Achivi,

obrutaque est mecum virtutis gratia nostrae!

ne facite! utque meum non sit sine honore sepulcrum,

placet Achilleos mactata Polyxena manes!'

"El Atrida había amarrado sus naves en la costa tracia hasta que el mar estuviese calmado, hasta que el viento fuese más favorable; de repente aquí surge de la tierra, resquebrajada en gran extensión, Aquiles tan imponente como solía ser cuando vivía y, en actitud amenazante, mostraba el rostro de aquel momento en el que, enfurecido, atacó a Agamenón con injusto hierro, y dice: “¿Os vais, aqueos, sin acordaros de mí y conmigo 
ha sido sepultado el pago de mi valor? ¡No lo hagáis! y, para que mi sepulcro no esté privado de honores, que aplaque los manes de Aquiles el sacrificio de Políxena”.

a primera vista pueden parecer una mera transposición de las expuestas en dos lugares de la Hécuba euripídea: la información del espectro de Polidoro en 36-41 y las del triste mensaje que lleva a la reina el coro de troyanas en 109-115; sin embargo, Ovidio no se limita a repetir a Eurípides sino que lo va reescribiendo para conducir al lector con sus personales indicios hasta la doliente madre. Así, aunque aparentemente sólo dice que están en la costa de Tracia esperando vientos favorables, los vv. 439-440 ("El Atrida había amarrado sus naves en la costa tracia hasta que el mar estuviese calmado, hasta que el viento fuese más favorable") no intentan reproducir simplemente lo dicho en Hec. 35-36 ("Todos los Aqueos, anclando sus naves, permanecen a la espera en la costa de esta tierra Tracia”), pues la mención expresa de Atrides no es tan sólo la singularización de los aqueos en el jefe de la expedición, sino que Ovidio quiere sugerir a sus lectores el estrecho paralelismo entre un padre, el ánax andrôn, que, para conseguir vientos favorables en el viaje de ida a Troya, tuvo que sacrificar a su hija ${ }^{9}$, y una madre, a la que hemos venido en denominar "ánax gynaikón", cuya hija va a ser inmolada a fin de hacer propicio el mar para el regreso.

De igual modo, los siguientes versos de Ovidio, 441-444:

hic subito, quantus, cum viveret, esse solebat, exit bumo late rupta similisque minanti temporis illius vultum referebat Achilles, quo ferus iniustum petiit Agamemnona ferro.

\footnotetext{
9 El sacrificio de Ifigenia está concisamente narrado en Met. 12. 24-38; también para esta inmolación había sido determinante la elocuencia de Ulises, como estaba ya en los Cypria y se deduce de IA 1362 y en otros lugares de los que se hace eco Ovidio en Met. 12. 181-195, en que el propio itacense se jacta de ello. Este paralelismo lo reflejaba Eurípides, puesto que en la Hécuba había sido Ulises el encargado de convencer a la reina de que debía obedecer el acuerdo de los griegos y entregar a su hija. En Ovidio, que prescinde del de Ítaca, el paralelismo viene determinado por la necesidad de un mar propicio.
} 
"De repente aquí surge de la tierra, resquebrajada en gran extensión, Aquiles tan imponente como solía ser cuando vivía y, en actitud amenazante, mostraba el rostro de aquel momento en el que, enfurecido, atacó a Agamenón con injusto hierro".

tampoco han de entenderse sólo como una mezcla de Hec. 37-39:

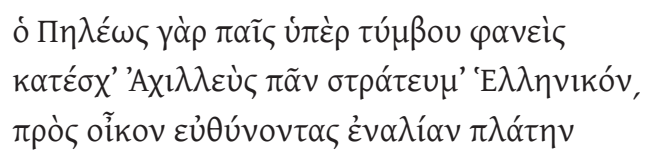

"Pues el hijo de Peleo, Aquiles apareciéndose sobre su tumba ha detenido todo el ejército heleno que en dirección a su casa volvía los remos marinos".

y 109-113:

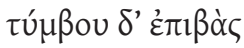

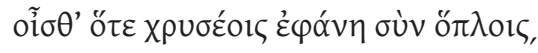

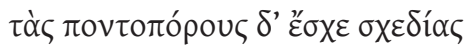

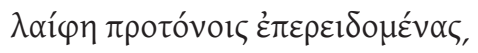
$\tau \alpha ́ \delta \varepsilon \theta \omega v ́ \sigma \sigma \omega v$

"Sabes que colocándose sobre su tumba se apareció con sus doradas armaduras y retuvo las naves que atraviesan el ponto, cuando tenían ya tensadas las velas con cabos".

En efecto, frente a lo que precisan en Hécuba el espectro de Polidoro y las cautivas acerca de que Aquiles hace su aparición sobre su tumba (phaneis en el v. 37 y epháne en el v. 110) para que, al ser avistada su enorme figura, las naves se detuvieran cuando se encaminaban a las costas tracias, Ovidio, confiriendo coherencia al relato, sugiere que el sacrificio de Políxena se realice en honor de Aquiles pero no necesariamente en su tumba, pues eso significaría arriesgarse a cruzar un mar que, como ha dicho, no es amicus; es, en todo caso, el espectro de Aquiles el que ha atravesado el estrecho, ya que surge de la tierra y no de su túmulo. Ovidio, que sabe al igual que sus lectores que ya en Homero (Od. 24. 71-84) la tumba del 
Pelida está situada en la Tróade, no quiere que Hécuba sea informada de la muerte de su hija por ningún emisario, sino que la convertirá en madre dolorosa haciéndola conocer de primera mano todo el suceso, para lo cual el escenario tiene que estar forzosamente en Tracia. La figura de Aquiles se engrandece porque la tempestad, que ha obligado al Atrida a buscar refugio, no responde a que Posidón haya atendido la petición de Atenea igual que en Troyanas, sino que se debe a que el propio Aquiles, como si de una divinidad se tratara, ha impedido el avance de las naves para reclamar una víctima propiciatoria.

El paralelismo con lo sucedido en el caso de Ifigenia vuelve a ser manifiesto. Ésa es la razón de que la descripción de la epifanía de Aquiles en Metamorfosis sea mucho más vívida e impactante que las palabras de Polidoro e incluso que las del coro, que recuerdan sólo que portaba doradas armas; más parece estar inspirada en alguna de las muchas representaciones iconógraficas que había del héroe, basadas, por supuesto, en la iliádica cólera del Pelida, pues el amenazador aspecto de los versos 441-443 es eco de la fórmula homérica de Il. 1. 148: "mirándolo torvamente, Aquiles el de los pies ligeros, le dijo", que, referida a Aquiles, volvemos a leer en 22. 260 y 344 y en 24. 559; de igual manera el ataque a Agamenón del v. 444, sin duda haría evocar a los lectores de Ovidio el momento en que es obstaculizado el Pelida por Atenea cuando se apresta a agredir al Atrida, en Il. 1. 194: "y sacó de la vaina la gran espada”.

El narrador épico hace hablar a Aquiles reclamando la inmolación de Políxena, en 445-448:

'inmemores'que 'mei disceditis, ' inquit 'Achivi, obrutaque est mecum virtutis gratia nostrae! ne facite! utque meum non sit sine honore sepulcrum, placet Achilleos mactata Polyxena manes!"

"Y dice: '¿Os vais, aqueos, sin acordaros de mí y conmigo ha sido sepultado el pago de mi valor? ¡No lo hagáis! y, para que mi sepulcro no esté privado de honores, que aplaque los manes de Aquiles el sacrificio de Políxena'." 
y combina el discurso indirecto de Polidoro de Hec. 40-41:

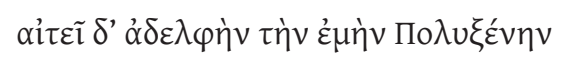

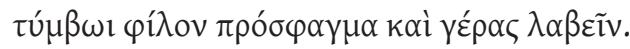

"Exige tomar a mi hermana como don grato a su tumba y como un honor".

con las palabras del héroe reproducidas en estilo directo por el coro en 113-115:

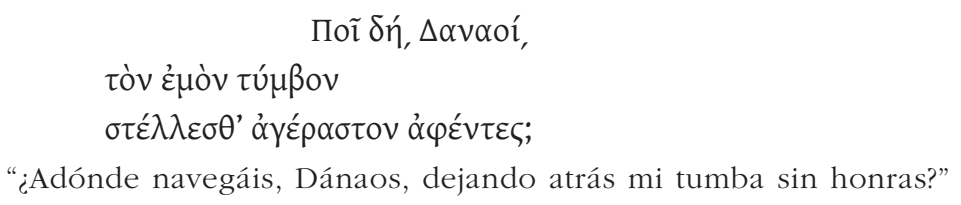

Para la escena en que Políxena es arrancada del regazo de su madre, Ovidio en Met. 13. 449-452:

dixit et inmiti sociis parentibus umbrae

rapta sinu matris, quam iam prope sola fovebat,

fortis et infelix et plus quam femina virgo/

ducitur ad tumulum diro que fit hostia busto.

"Dijo y arrancada por los aliados, que obedecían a la cruel sombra, del regazo de su madre, a la que ya casi ella únicamente abrazaba, la valerosa y desgraciado doncella y más que mujer es guiada al túmulo y se convierte en víctima para la funesta pira”.

actualiza fielmente aquellos emotivos momentos de la tragedia en que el coro anuncia a Hécuba que vendrán a arrebatarle a su hija (141-143):

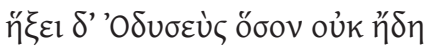

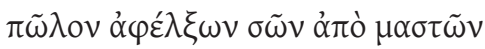

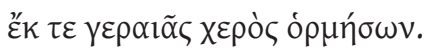

"Llegará Ulises, si no ha llegado ya, para arrancar a la potrilla de tus pechos y alejarla de tu mano de anciana"

a la vez que condensa el diálogo entre Hécuba y Políxena (155-215). Señalemos, además, que el v. 450 ("arrancada del regazo de su madre, a la 
que ya casi ella únicamente abrazaba") sin duda evocaría en los conocedores de la Hécuba euripídea los versos en que la madre expresa su deseo de morir en lugar de su hija o, al menos, de ser inmoladas juntas, pues no se separará de ella, según dice tajantemente en 398 y 400: "Cual hiedra a una encina, así me abrazaré a esta....ique no me soltaré de esta hija por mi voluntad!", palabras que sin duda acompañaría con el gesto de abrazar estrechamente a la muchacha.

El relato de la inmolación de la doncella es otra importante muestra del modus narrandi ovidiano, ya que traduce a código épico escenas de tragedia de gran patetismo, en las que juegan un importante papel los emisarios encargados de notificar la decisión de los aqueos de llevarse a la joven víctima y de informar de la ejecución del sacrificio. Ovidio suprime el papel de esos personajes masculinos, Ulises y Taltibio, ya que está escribiendo una "tragedia de mujeres"; para conferir fuerza dramática a la narración hace algo impensable en un drama: presta su palabra a la propia víctima en "escena", mientras se ofrece para ser degollada (13 457-473), sustituye al emisario de tragedia describiendo la acción y, de aquello que Taltibio refiere a Hécuba una vez consumada la funesta matanza, selecciona lo que le parece más apropiado para realzar el pathos y omite los preparativos del sacrificio, presentando la acción en el momento en que Neoptólemo se dispone a consumarlo (455-456):

utque Neoptolemum stantem ferrumque tenentem;

inque suo vidit figentem lumina vultu.

"Y cuando vio a Neoptólemo de pie y sosteniendo la espada, y cuando lo vio clavando los ojos en su rostro".

Con todo, sigue muy fielmente el texto del trágico, Hec. 543-544:

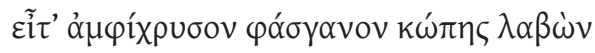

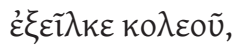

"Después, cogiendo por el puño la espada por ambos lados guarnecida de oro" 
pero con inversión del orden, pues Ovidio, acordándose de que para Taltibio en Hec. 562 la frase más heroica de todas son las últimas palabras de Políxena, 563-565:

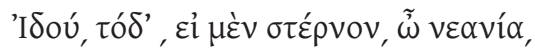

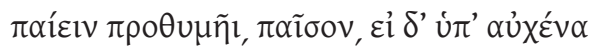

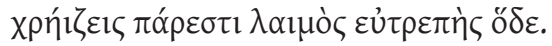

"Mira, aquí está, si quieres golpear, joven, mi pecho, golpéalo; pero si deseas darme en el cuello, aquí está dispuesta mi garganta”.

las traslada al comienzo de la presencia de la joven en "escena", 457-459:

'utere iamdudum generoso sanguine' dixit 'nulla mora est; at tu iugulo vel pectore telum conde meo'.

"Utiliza al instante mi noble sangre (no hay demora) o hunde tú tu arma en mi garganta o en mi pecho".

con la "acotación", 459: "y descubrió a la vez la garganta y el pecho", que sigue reproduciendo palabras de Taltibio, pero dichas inmediatamente antes, en los vv. 560-561:

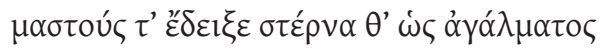
кó $\lambda \lambda 1 \sigma \tau \alpha$.

"Mostró sus senos y su hermosísimo pecho, como los de una estatua".

Queda claro, pues, que, además de efectuar una inversión de los momentos euripídeos, lo que Eurípides sitúa fuera de la vista lo presenta Ovidio en escena.

La condición de esclava de Políxena y el rechazo que tal situación le provoca en la tragedia (357 ss. y 552 ss.) apenas es significativo en Metamorfosis, donde adquiere mayor relevancia la esclavitud de Hécuba, ya que en torno a ella gira todo el relato; de ahí además que la joven víctima no lamente sus truncadas bodas, su carencia de hijos, su futuro en suma (Hec. 416 ss.), y sólo diga en 460: 
'scilicet haud ulli servire Polyxena vellem'.

"En efecto, yo, Políxena, no querría servir a nadie".

No cabe duda de que esa sencilla aspiración de no querer vivir en esclavitud es altamente significativa: su deseo de morir antes que ser cautiva intenta neutralizar el efecto propiciatorio del sacrificio que Neoptólemo ha rogado en la libación a su padre en Hec. 534-541; además aclara la rotundidad del v. 461:

haud per tale sacrum numen placabitis ullum.

"Mediante tal sacrificio no aplacaréis a divinidad alguna".

ya que Políxena parece presentarse voluntariamente como víctima, una actitud que anula la venganza de Aquiles, pues es un ofrecimiento para ver cumplidos sus deseos de no vivir como esclava. Ovidio, además, introduce unos versos, que no son deudores del parlamento de Taltibio, a fin de incorporar a Hécuba, aparentemente olvidada, al relato: del numen que es el padre de Neoptólemo, el sacerdote del sacrificio de la hija, se pasa a la madre de la víctima, no tanto como causante de la muerte de Aquiles sino como la desgraciada mater orba en que devendrá, en los vv. 462-464:

mors tantum vellem matrem mea fallere posset:

mater obest minuitque necis mibi gaudia, quamvis

non mea mors illi, verum sua vita tremenda est.

"Tan sólo querría que mi muerte pudiera hurtársele a mi madre; mi madre es un obstáculo y disminuye mi goce de la muerte, aunque no ha de llorar ella mi muerte sino su vida”.

unos versos que, por otra parte, son recuerdo de las palabras de la reina en Hec. 231-233:

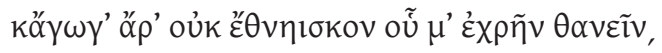

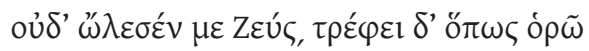

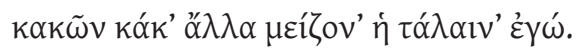


"Yo, en verdad, no morí cuando debí morir, ni Zeus me destruyó, sino que me mantiene con vida para que contemple, desventurada de mí, desgracias más grades que las desgracias pasadas".

y que con el juego epanáforico y de variatio (mors, necis), de polyptoton (matrem, mater) y de oxymoron (mors, necis / gaudia, vita) dotan al relato de un patetismo tan elevado como los quejidos de la reina en el drama.

Repetición de la tragedia y reiteración de las intenciones de Ovidio se observa en los vv. 465-473:

vos modo, ne Stygios adeam non libera manes,

ite procul, si iusta peto, tactuque viriles

virgineo removete manus! acceptior illi,

quisquis is est, quem caede mea placare paratis,

liber erit sanguis. siquos tamen ultima nostri

verba movent oris, Priami vos filia regis,

non captiva rogat, genetrici corpus inemptum

reddite, neve auro redimat ius triste sepulcri,

sed lacrimis! tum, cum poterat, redimebat et auro'.

"Vosotros tan sólo, para que no me acerque yo a los manes estigios con falta de libertad, marcháos lejos, si pido algo justo, y apartad vuestras manos de hombres del contacto con una doncella. Será más aceptable para aquél, cualquiera quien sea aquél a quien os disponéis a aplacar con mi sacrificio, una sangre libre; sin embargo, si a algunos os conmueven las últimas palabras de mi boca (os lo ruega la hija del rey Príamo, no una cautiva), devolved a mi madre el cuerpo sin que tenga que comprarlo, y que no pague el derecho a un sepulcro con oro causante de tristeza sino con lágrimas. Entonces, cuando podía, también lo pagaba con oro".

En las palabras con las que Políxena suplica que ningún hombre la toque, v. 465 :

vos modo, ne Stygios adeam non libera manes.

"Vosotros tan sólo, para que no me acerque yo a los manes estigios con falta de libertad". 
el poeta emplea el término libera con la misma ambigüedad que Eurípides eleuthéra en Hec. 550 ("dejadme libre, para que libre muera"), pues tanto pueden significar libre de ataduras o de sujeción, cuanto no esclava; es precisamente en esta segunda acepción en la que incide al decir en 13. 467-469:

acceptior illi,

quisquis is est, quem caede mea placare paratis,

liber erit sanguisque,

"Será más aceptable para aquél, cualquiera quien sea aquél a quien os disponéis a aplacar con mi sacrificio, una sangre libre".

versos que de nuevo insisten en la poca consideración en que la víctima tiene al destinatario del sacrificio, al que antes, tal vez con ironía, ha mencionado como numen y ahora simplemente como quisquis is est ("cualquiera quien sea aquél"). Esa misma idea de libera como no esclava se repite en 470-471: "os lo ruega la hija del rey Príamo, no una cautiva", donde Ovidio sin duda tiene presente que Políxena dice que siendo una princesa no desea llegar como esclava al Hades en Hécuba 551-552; son palabras con las que la joven víctima quiere aprovechar, en las Metamorfosis, el estremecimiento que entre los aqueos despertarán sus ultima verba (469-470), reflejo a su vez de la emoción contenida en la tragedia, pero empleadas por el épico romano para llevar la atención de nuevo hacia Hécuba y resaltar una previsión de futuro anclada en una similar situación del pasado: que, aunque el padre de Neoptólemo devolviera a Príamo a cambio de oro el cadáver de su hijo, la madre de Políxena podrá reccuperar el cuerpo inerte de su hija sin pagar nada por ella, vv. 469-473:

siquos tamen ultima nostri

verba movent oris, Priami vos filia regis, non captiva rogat, genetrici corpus inemptum

reddite, neve auro redimat ius triste sepulcri, 
sed lacrimis! tum, cum poterat, redimebat et auro'.

"si a algunos os conmueven las últimas palabras de mi boca (os lo ruega la hija del rey Príamo, no una cautiva), devolved a mi madre el cuerpo sin que tenga que comprarlo, y que no pague el derecho a un sepulcro con oro causante de tristeza sino con lágrimas. Entonces, cuando podía, también lo pagaba con oro."

No se trata de una mera ingenuidad de la joven ${ }^{10}$, sino un deseo de forzar el paralelismo con el final de la Ilíada, cuando Príamo, mucho más padre que rey, conmueve hasta las lágrimas a Aquiles y consigue recuperar el cadáver de Héctor, pero, como aún es rey, lo logra también con múltiples presentes, entre los cuales había 10 talentos de oro (Il. 24. 228-236). En este parlamento podemos observar con claridad la transposición épica que Ovidio realiza de un elemento trágico: Políxena ruega en "escena" que su madre no sufra, con lo que ha transferido la dolorosa situación de la Hécuba del drama euripídeo, sus súplicas y el normal espíritu de sacrificio de una madre a la aceptación por parte de la joven de su inmolación, lo que constituye una muestra de la enorme generosidad de una hija que prefiere la muerte antes de ver la aflicción de su madre, una joven que se comporta todavía como princesa y quiere que su madre sea tratada como una reina; tal generosidad de Políxena es indicio de que es digna hija de Hécuba y que es de noble cuna, lo que evidencia el poeta al unir sentimientos y tradición literaria, al diseccionar el alma de una joven que va a morir y extraer lo mejor de ella. El narrador en los vv. 474-480:

Dixerat, at populus lacrimas, quas illa tenebat, non tenet; ipse etiam flens invitusque sacerdos praebita coniecto rupit praecordia ferro. illa super terram defecto poplite labens pertulit intrepidos ad fata novissima vultus: tunc quoque cura fuit partes velare tegendas, cum caderet, casti que decus servare pudoris.

10 Tal es la opinión de F. Bömer 1982: ad loc., de quien disentimos. 
"Había dicho, mas el pueblo no contiene las lágrimas, que ella contenía; incluso el propio sacerdote, llorando y mal de su grado, hundiendo el hierro desgarró el pecho que se le ofrecía. Ella, cayendo sobre la tierra al fallarle las rodillas, mantuvo hasta el último momento su animoso rostro: también entonces se preocupó, al caer, de cubrir las partes que debían ser ocultadas y de conservar el decoro de un casto pudor".

reproduce los mismos detalles que describe Taltibio a Hécuba en 566570, es decir la vacilación de Neoptólemo, emocionado por los ultima verba de Políxena, y la famosa escena de la pudicitia de la doncella al caer:

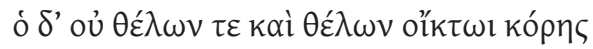

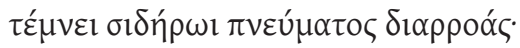

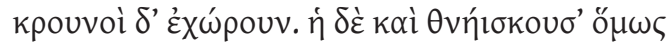

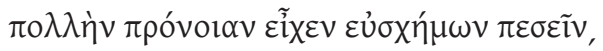

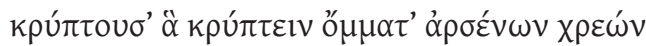

"Y él, queriendo y no queriendo por piedad hacia la muchacha, le corta con el hierro las salidas del aire. Saltaban chorros. Y ella, aunque moribunda, tenía, con todo, gran cuidado de caer en buena postura, ocultando lo que debe ocultarse a la mirada de los hombres".

La innovación que realiza Ovidio en esta tragedia de mujeres consiste en que, puesto que las troyanas y la propia Hécuba no reciben la información de ningún mensajero ya que están presentes, son las cautivas, y no los aqueos como en el drama, las que recogen inmediatamente el cuerpo sin vida de Políxena e inician como plañideras los ritos funerarios que derivan en lamentos por la madre, recordando los tópicos tradicionales referidos a la reina troyana, que pueden evocar algunos momentos de las Troyanas de Eurípides. Tales gemidos por hija y madre tienen su clímax en la apóstrofe proléptica de los vv. 483-485:

teque gemunt, virgo, teque, o modo regia coniunx, regia dicta parens, Asiae florentis imago, nunc etiam praedae mala sors, 
"Y te lloran a ti, doncella, y a ti, llamada hace poco real esposa, llamada regia madre, símbolo de la floreciente Asia, ahora desgraciado sorteo incluso de un botín".

que, según la función que detectáramos en este tipo de apóstrofes, nos pone sobre aviso de que la tragedia no ha concluido y de que las desgracias se verán incrementadas. Y así es, pues falta el treno de la madre y, sobre todo, el descubrimiento del cadáver de Polidoro.

El treno de Hécuba (13. 494-532) es uno de los monólogos de lamento contenidos en las Metamorfosis, que, pese a ser un elemento estructural propio del drama, tiene raigambre épica ya que vemos que está fuertemente influido por dos discursos de la Ilíada: el de la despedida de Héctor (6. 441-465) y las quejas de Andrómaca por la muerte de su esposo (24. 724745). Con todo, el análisis pormenorizado del contenido revela que los detalles proceden de las dos tragedias de tema troyano de Eurípides. Común a los precedentes épicos y de tragedia es que las mujeres no hacen la guerra, pero es mucho más desgarrado el lamento de la Hécuba ovidiana, con su insistente repetición y oposición de términos (femina, ferro y tutam) cecidisti), de Met. 13. 497-498:

at te, quia femina, rebar

a ferro tutam: cecidisti et femina ferro.

"Pero a ti, por ser mujer, te creía a salvo del hierro; incluso siendo mujer has muerto por el hierro".

Igualmente tópica es la idea de los numerosos hijos habidos y perdidos a manos de Aquiles, si bien Ovidio engrandece esa imagen para realzar, aún más si cabe, la desgracia que le sobreviene a esa mater orba; incluso innova al hacer que Hécuba en el v. 502 de su treno recuerde que: "dije: 'al menos ahora no ha de ser temido Aquiles' ", para contrarrestar las palabras dichas inmediatamente antes sobre la triste realidad del momento, mediante la insistencia de los vv. 503-504: "La propia ceniza del sepultado se ensaña contra este linaje; incluso en su sepulcro lo hemos sentido como enemigo", 
insistencia que culmina en el v. 505: "fui fértil para el Eácida", eco indubitado de las palabras de Andrómaca a Astianacte de Tr. 747-748:

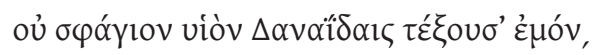

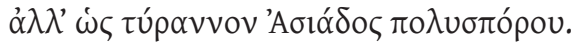

"A ti, hijo mío, no te engendré para que fueras víctima en proveccho de los Danaidas sino como soberano de la rica Asia”.

Ovidio asimila así a las dos madres más desgraciadas del linaje dardanio, confiriendo a este momento un patetismo que a nuestro parecer $^{11}$ no responde a la mera acumulación criticada por Escauro según leemos en Séneca Contr. 9. 5, 17:

Et propter hoc et propter alia quibus orator potest poetae similis videri solebat Scaurus Montanum inter oratores Ovidium vocare; nam et Ovidius nescit quod bene cessit relinquere. Ne multa referam quae Montaniana Scaurus vocabat, uno boc contentus ero: cum Polyxene esset abducta ut ad tumulum Achillis immolaretur, Hecuba dicit [13. 503-504]: cinis ipse sepulti / in genus boc pugnat. Poterat hoc contentus esse; adiecit [504]: tumulo quoque sensimus hostem. Nec hoc contentus est; adiecit [505]: Aeacidae fecunda fui. Aiebat autem Scaurus rem veram: non minus magnam virtutem esse scire dicere quam scire desinere.

"A causa de esto y de otras cosas por las que el orador puede parecer semejante a un poeta, Escauro solía llamar a Montano 'Ovidio entre los oradores'; en efecto tampoco sabe Ovidio poner fin a lo que le ha salido bien. Para no recordar muchas cosas que Escauro designaba como propias de Montano, me contentaré con esto solamente: al ser arrebatada Políxena para ser inmolada junto al túmulo de Aquiles, dice Hécuba: 'la propia ceniza del sepultado se ensaña contra este linaje'. Podía estar contento con esto; añadió: 'incluso en su sepulcro lo hemos sentido como enemigo'. Y no se contentó con esto tampoco; añadió: 'fui fértil para el Eácida'. Escauro, por tanto, decía la verdad: no es menos grande virtud saber decir como saber dejar de decir".

11 No creemos que, en esta ocasión, el tantas veces dado al humor Ovidio (cf. R. M ${ }^{a}$ Iglesias-M $M^{a}$ C. Álvarez, 2005: 403-419) quisiera superar con la reiteración el excesivo dramatismo de la situación provocando una relajación en la tensión narrativa. 
pues una madre, que acaba de perder a su hija de forma tan cruel, forzosamente tiende a repetir sin cesar reproches contra el que ha provocado esa muerte, máxime si, como en el caso de Hécuba, el causante la ha dejado orba, sin hijos. La reina, consciente del gran poder que tuvo y de haberlo perdido todo y de su condición de esclava, continúa hablando, en Met. 13. 505-520:

iacet Ilion ingens,

eventuque gravi finita est publica clades,

sed finita tamen: soli mibi Pergama restant,

in cursuque meus dolor est. modo maxima rerum,

tot generis natisque potens nuribusque viroque,

nunc trahor exul, inops, tumulis avulsa meorum,

Penelopes munus, quae me data pensa trabentem

matribus ostendens Ithacis 'haec Hectoris illa est

clara parens, haec est' dicet 'Priameia coniunx',

postque tot amissos tu nunc, quae sola levabas

maternos luctus, hostilia busta piasti!

inferias hosti peperi. quo ferrea resto?

quidve moror? quo me servas, annosa senectus?

quo, di crudeles, nisi uti nova funera cernam,

vivacem differtis anum? quis posse putaret

felicem Priamum post diruta Pergama dici?

"Yace postrada la enorme Ilio, y con un penoso suceso ha acabado la desgracia del pueblo, pero con todo ha terminado; para mí sola permanece Pérgamo, y mi dolor sigue su curso. Hasta hace poco la más importante de todo, poderosa por tantos yernos e hijos, nueras y marido. Ahora soy arrastrada en mi exilio, pobre, arrancada de los túmulos de los míos, presente para Penélope, la cual, mostrándome a las matronas de Ítaca a mí, cuando arrastre la tarea encomendada, dirá: 'Ésta es la famosa ilustre madre de Héctor, ésta es la esposa de Príamo', iy después de que tantos se han perdido, ahora tú, la única que aliviabas mi luto de madre, has aplacado con tu sacrificio la pira del enemigo! He parido ofrendas fúnebres para un enemigo. ¿Para qué resisto fuerte como el hierro? ¿O qué espero? ¿Para qué me reservas, añosa vejez? ¿Para qué, dioses crueles, a no ser para contemplar nuevos funerales, alargáis la vida a una anciana? ¿Quién creería que podría ser llamado feliz Príamo después de la destrucción de Pérgamo?". 
quejas que son ecos de Troyanas y de Hécuba en que se reflejan los momentos previos a tener constancia de la muerte de Políxena. Así, en Tr. 104-106, dice la abatida soberana:

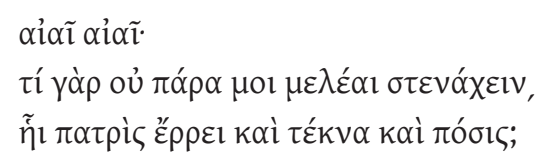

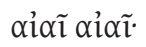

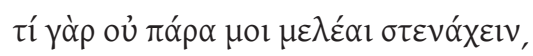

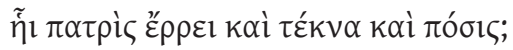

"¡Ay, ay, ay! ¿Qué más me falta para llorar, desgraciada de mí, a quien se le han ido patria, hijos y esposo?".

y continúa en 140-142:

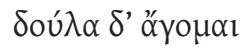

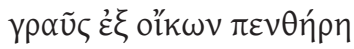

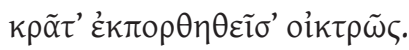

"Soy llevada de mi casa como una esclava vieja, llena de dolor, al haber sido destruido mi poder, lastimeramente".

Y en diálogo con el coro dice en 190-199:

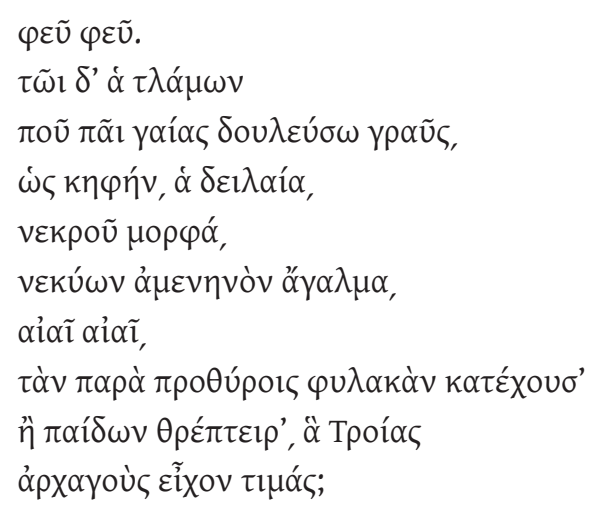

“¡Ay, ay! ¿a quién, cómo y dónde serviré yo como esclava, esta vieja resignada, como una zángana, esta miserable, figura de cadáver, efigie fugaz de la muerte? jay, ay! ¿montando guardia a la entrada de una puerta, cuidando niños, yo que tenía el honor de gobernar Troya?"

Y de modo especial recoge lo dicho por la propia Hécuba en 474-476: 


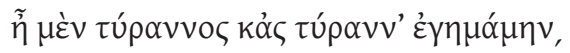

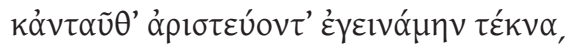

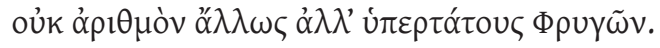

"Yo era reina y me casé con un rey, y entonces engendré hijos superiores, no solamente en número sino en excelencia, a todos los Frigios".

y por el mensajero Taltibio, cuando en Hec. 492-496 aparece en escena y descubre a la reina, a la que más tarde relatará cómo se desarrolló el sacrificio de Políxena:

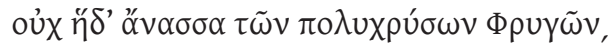

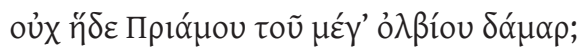

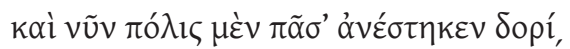

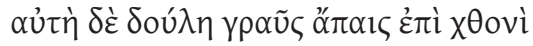

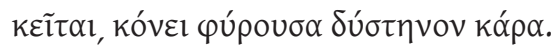

"¿No es ésta la reina de los Frigios ricos en oro? ¿No es ésta la esposa de Príamo, el muy dichoso? Y ahora toda su ciudad está devastada por la lanza, y ella, esclava vieja sin hijos, yace por tierra, manchando de polvo su desgraciada cabeza".

Ovidio con tales precedentes quiere resaltar ahora la soledad de Hécuba como madre del homérico Héctor en 13. 512-513:

\section{"baec Hectoris illa est} clara parens, haec est" dicet "Priameia coniunx,"

" 'Ésta es la famosa ilustre madre de Héctor, ésta es la esposa de Príamo'."

presuponiendo las palabras que dirá Penélope cuando muestre a su nueva esclava, vieja y sin valor alguno, que evocan los tristes agüeros que para sí vaticina Hécuba en Tr. 489-497:

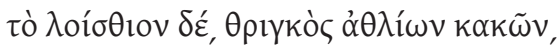

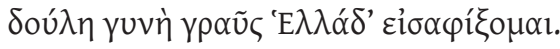
¿ $\delta$ '

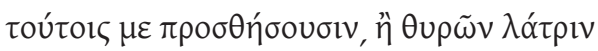




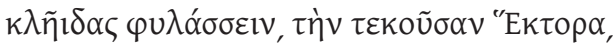

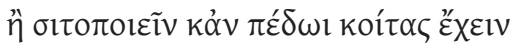

$$
\begin{aligned}
& \text { }
\end{aligned}
$$

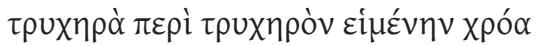

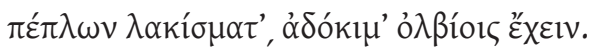

"Y por último, el colmo de todos los males, como una vieja mujer esclava voy a llegar a la Hélade, lo más inapropiado para esta vejez, me encargarán de estas cosas: custodiar las llaves como portera yo la que engendró a Héctor, o a fabricar el pan, y a tener en el suelo un camastro para mis arrugados lomos en vez de mis lechos reales, a vestir este andrajoso cuerpo con andrajosos retales de peplos, insulto para los ricos".

Con el tópico del padre muerto que ya no contemplará más desgracias de los suyos, la Hécuba ovidiana en 13. 521-522, al decir:

felix morte sua est: nec te, mea nata, peremptam adspicit et vitam pariter regnum que reliquit!

"Es feliz con su muerte: jno te contempla asesinada, hija mía, y abandonó a la vez la vida y el reino!"

aúna las palabras que reina y coro intercambian en el éxodos de Troyanas 1312-1316:

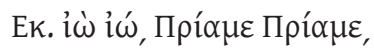

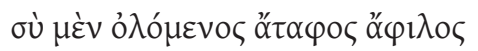

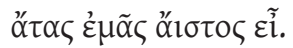

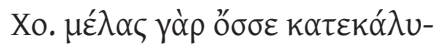

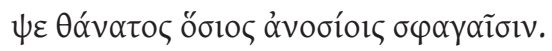

"He.- ¡Oh, oh! ¡Príamo, Príamo! ¡Tú, muerto, insepulto, sin amigos, no ves mis desgracias! Co.- Pues, piadosa la negra muerte cubrió los ojos con impío degüello".

con el lamento que emite Evandro por la muerte de su hijo Palante, consolándose de que su esposa ya fallecida no pueda verlo, en Aen. 11. 158-161: 
tuque, o sanctissima coniunx,

felix morte tua neque in bunc seruata dolorem!

contra ego uiuendo uici mea fata, superstes restarem ut genitor

"Y tú, oh santísima esposa, ¡feliz en tu muerte al no haber sido reservada para este dolor! Por el contrario, yo viviendo vencí mi destino para sobrevir siendo su padre".

La simplificación de las escenas ulteriores en Metamorfosis no disminuye el dramatismo de la acción sino que lo intensifica aún más, pues sin duda no sólo el hecho de que Hécuba haya sido testigo directo de la inmolación de Políxena sino también la pérdida de sus atribuciones de reina contribuyen a agrandar el pathos. Tengamos presente que en la Hécuba de Eurípides ha recibido a través del mensajero Taltibio la orden de enterrar a su hija, que se dispone a realizarlo y que envía a una sierva para que le traiga una urna llena de agua de mar y esa sierva será la que, en lugar de la urna, volverá portando el cadáver de Polidoro, mientras que en Metamorfosis tan sólo se repite el detalle de la petición del recipiente, ya que el verso 534 ('date, Troades, urnam!') resume Hec. 609-610:

$\sigma \dot{v} \delta^{\prime} \alpha \tilde{u} \lambda \alpha \beta$ $\sigma \alpha \tau \varepsilon \tilde{u} \chi \circ \varsigma, \alpha \propto \alpha x \alpha i ́ \alpha \lambda \alpha ́ \tau \rho 1$,

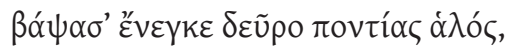
"Y tú, vieja esclava, cogiendo una vasija tras meterla en el el agua del mar, tráela aquí".

pero Ovidio innova al hacer que sea la propia Hécuba la que se dirija al mar y allí, de improviso, descubra el cuerpo sin vida de su hijo, al que como único superviviente y consuelo de sus padecimientos se ha referido en los últimos versos del treno (527-530). Frente a las muchas palabras de dolor que emite en Troyanas y en Hécuba, en Ovidio hay silencio; mas, tal vez recordando una frase de la Hécuba euripídea que es tan sólo una frase más entre todos los lamentos, la del verso 683: "he muerto triste de mí y ya no existo más", el narrador parece indicarnos que la reina casi se muere de dolor, pues sus reacciones, como vemos en los vv. 538-544: 
obmutuit illa dolore,

et pariter vocem lacrimasque introrsus obortas

devorat ipse dolor, duroque simillima saxo

torpet et adversa figit modo lumina terra,

interdum torvos sustollit ad aethera vultus,

nunc positi spectat vultum, nunc vulnera nati,

vulnera praecipue.

"Queda muda ella por el dolor, y a la vez el propio dolor le consume las palabras y las lágrimas vertidas por dentro, y muy semejante a un duro peñasco queda paralizada y clava unas veces los ojos en la tierra que tiene enfrente, otras veces alza su torvo rostro hacia el cielo, ora contempla el rostro de su hijo allí tendido, ora sus heridas, sobre todo las heridas"

corresponden a una conversión en piedra, tipo de transformación que, según hemos dicho en otro lugar ${ }^{12}$, puede ser entendida como una especie de colapso o de ataque al corazón y que como tal puede producir la muerte inmediata o una paralización transitoria; es el tipo de reacción inesperada ante un profundo dolor, por regla general precedido por el espanto y consternación ante el hecho que lo motiva, que Ovidio ha desarrollado magistralmente en el caso de Níobe, y que ha repetido en las inmovilizaciones de dos padres: la propia Hécuba y Dedalión ${ }^{13}$.

Con mayor inmediatez en el relato ovidiano de lo que ocurre en el drama griego, Hécuba resucita impelida por la cólera y maquina la venganza, según leemos en los vv. 544-546:

seque armat et instruit ira

qua simul arsit ...

ulcisci statuit poenaeque in imagina tota est.

"Se arma y se provee de cólera. Tan pronto como ardió con ella ... decidió vengarse y toda ella está inmersa en la imaginación del castigo".

\footnotetext{
12 Cf. R. M M Iglesias-M $^{a}$ C. Álvarez, 1998: 381-382.

13 Por lo tanto, no coincidimos con J.P. Néraudau, 1981: 38-44, para quien el mutismo al descubrir el cadáver de Polidoro es un indicio la regresión de Hécuba a la animalidad.
} 
Nada dice Ovidio en esta "tragedia troyana" sin hombres de la conversación de Hécuba con el Atrida en la que le hace saber la traición de Poliméstor, ni de cómo la pusilanimidad de Agamenón y su miedo a que su pueblo le critique si él es el autor del castigo a un aliado, mueve a la doliente soberana, ya esclava, a solicitar al rey de reyes complicidad en la venganza que ha decidido llevar a cabo con la ayuda de las troyanas. En el relato épico es la propia mater orba la que acude en busca del rey tracio y lo engaña con los mismos argumentos utilizados en el drama (Hec. 1000-1022): el oro que despertará su insaciable avaricia, Met. 13. 551-553:

vadit ad artificem dirae, Polymestora, caedis conloquiumque petit; nam se monstrare relictum velle latens illi, quod nato redderet, aurum.

"Va ante el artífice de la cruel matanza, Poliméstor, y pide una entrevista; pues dice que ella quiere mostrarle un oro que había dejado oculto, que debía entregar a su hijo".

lo que estimula tanto la codicia del traidor que el poeta, en lugar de repetir las palabras de halago que pronuncia en su salutación en Hec. 953-954, se limita a constatar que habló con lisonjeras palabras (vv. 555-556: tum blando callidus ore / ... dixit) y la astucia se traduce en un juramento, ausente en el modelo trágico, que configura mejor todavía la maldad del único hombre que aparece en escena en la "Hécuba" ovidiana y justifica el aumento de la cólera de la vengativa madre, vv. 557-558:

omne fore illius, quod das, quod et ante dedisti, per superos iuro.

"Juro por los dioses del cielo que todo lo que das y lo que antes has dado habrá de ser de aquél".

La narratio épica permite una mayor plasticidad en la exposición de los sucesos sangrientos, que nunca podrían ser representados en la escena ática; por ello, la cruel venganza no se realiza en el interior de las tiendas 
de las cautivas como en el drama, sino que el poeta refiere con celeridad la especie de aquelarre de mujeres convocadas por Hécuba, quien de modo simultáneo produce en el rey ceguera y muerte. La fiereza de la reina contra el bárbaro y perjuro rey es brutal, vv. 561-564:

\section{digitos in perfida lumina condit}

expellitque genis oculos facit ira potentem

inmergitque manus foedataque sanguine sonti

non lumen neque enim superest, loca luminis haurit.

"Hunde sus dedos en los pérfidos ojos y extrae de sus mejillas los ojos (la cólera la hace dañina) y sumerge sus manos y, afeada con la sangre del culpable, le vacía no los ojos (pues nada queda) sino el lugar de los ojos".

Su acción sólo tendrá un paralelismo en la literatura latina en la autoceguera de Edipo, según Sen. Oed. 956-974; sin embargo, la atribulada madre ovidiana en su inmensa cólera no realiza el cruel crimen que sí llevan a cabo, en cambio, las troyanas de la tragedia: en el episodio de Metamorfosis no hay infanticidio. Dado que ceguera y muerte son simultáneas, Poliméstor no tiene tiempo para lanzar maldición alguna contra Hécuba, ni por tanto para predecir su futuro; ya ha hecho un doble vaticinio en la tragedia: que se subirá al mástil de la nave y desde ella se arrojará al mar y que se convertirá en perra (v. 1265) en un futuro cercano, pero en todo caso después de haberse subido a las naves que la alejarían de Tracia; y ese vaticinio lo eleva Ovidio a definitivo con su particular innovación, pues en el mismo escenario en que se comete el asesinato, y por tanto antes de subir a las naves, los súbditos tracios vengando a su rey consuman la profecía, v. 565-568:

clade sui Thracum gens inritata tyranni

Troada telorum lapidumque incessere iactu

coepit, at haec missum rauco cum murmure saxum

morsibus insequitur rictuque in verba parato

latravit, conata loqui. 
"El pueblo tracio, irritado por el asesinato de su rey, comenzó a atacar a la troyana lanzándole dardos y piedras; pero ella persigue con sus mordiscos una piedra que le ha sido arrojada con ronco murmullo y, al intentar hablar, con la boca preparada para emitir palabras ladró".

Finaliza el drama euripídeo con la orden de Agamenón a Hécuba de que entierre a sus dos hijos y suba a las naves; Ovidio, en cambio, al haber acelerado la metamorfosis, nada aclara al respecto; bien se puede deducir que las troyanas cuidarían de las exequias de los jóvenes y que "la perra Hécuba" vagaría por entre los sepulcros de sus hijos, de los que no habría sido definitivamente arrancada, y los cuidaría hasta que a su muerte se la enterrara en el lugar que la tradición ${ }^{14}$ llama sepulcro de la perra, muy cercano a los parajes donde se desarrollan las escenas de la tragedia.

Para concluir, podemos decir que omnia perdidimus, las palabras llenas de angustia que leemos en Met. 13. 527, pueden ser un eco de los lamentos que las mujeres vencidas emiten en múltiples lugares de Troyanas y de Hécuba de Eurípides, llorando la destrucción de su patria y su condición de cautivas que han de abandonar la Troya asolada. No obstante, cuando Ovidio las pone en boca de Hécuba, como frontera entre la inmolación de Políxena y el descubrimiento del cadáver del joven Polidoro, está transmitiendo la desesperación absoluta de una mujer que, poderosa antes social y políticamente, constata ahora que ha quedado en la más completa de las soledades al haber sucumbido todos los miembros de su familia, creyendo falsamente que su hijo pequeño aún estaba vivo. Todo el pasaje del destierro de las troyanas gira en torno a esta idea, los sufrimientos de Hécuba, para lo cual Ovidio utiliza su magistral técnica poética de mezcla de géneros, combinando datos que extrae del caudal épico, pero sobre todo del drama, consiguiendo un patetismo que llega incluso a superar el que emana de la actio trágica de los modelos conservados. De las obras literarias que de la antigüedad nos han llegado, es evidente la presencia de las dos tragedias

14 Ya Eur. Hec. 1273 habla del kynós ... sêma; para los autores helenísticos, cf. F. Bömer, ad loc. 
de Eurípides mencionadas, sin que podamos saber hasta qué punto ha habido influencia de otras obras teatrales posteriores, tanto griegas como romanas; el dramatismo de la situación tratada no impide, empero, que muchos de los detalles del episodio tengan su origen en la epopeya griega, tanto en la homérica como en las pertenecientes al ciclo épico de los posthomérica, así como es perceptible la huella de los libros segundo y tercero de la Eneida de Virgilio ${ }^{15}$. En las líneas precedentes hemos visto de qué modo el poeta compone sus "Troyanas" y en especial su "Hécuba" siguiendo el guión euripídeo, que va entretejiendo con datos procedentes del género épico para que, lo que aparentemente es igual, resulte absolutamente nuevo gracias a pequeñas pero importantes innovaciones.

\section{Bibliografía}

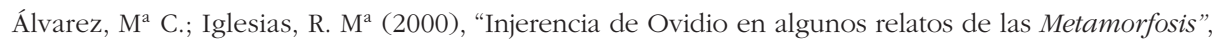
MD 45, 83-102.

Álvarez, Ma C.; Iglesias, R. Ma (eds.) (2009, 9ª ed.), P. Ovidio Nasón, Metamorfosis, Madrid.

Álvarez, Ma C.; Iglesias, R. Ma (2009), "La 'odiseica eneida' de las Metamorfosis", CFCEstLat, 29, 5-23.

Álvarez, Ma C.; Iglesias, R. M (2005), "Periplos en las Metamorfosis de Ovidio", en F.Carmona Fernández-J.M. García Cano, (eds.), Libros de viaje y viajeros en la Literatura y en la Historia, Murcia, pp. 11-37.

F. Bömer (1982), P. Ovidius Naso Metamorphosen, Komm. Bd. VI, Heidelberg.

G. D'Anna (1959), "La tragedia latina arcaica nelle "Metamorfosi'", en ACO, Atti del Convegno Internazionale Ovidiano, Roma, vol. II, pp. 217-234.

S. Döpp (1968), Virgilischer Einfluss im Werk Ovids, München.

O. S. Due (1974), Changing Forms: Studies in the Metamorphoses, Kopenhaguen.

C. Hollenburger-Rusch (2001), 'Liquitur in lacrimis'. Zur Verwendungder Tränenmotiv in den 'Metamorphosen' Ovids, Hildesheim-Zürich-New York.

R. Ma Iglesias-Ma C. Álvarez (1998), "Muerte versus cambio de forma”, en W. Schubert (ed.), Ovid-Werk und Wirkung. Festgabe für M. von Albrecht zum 65. Geburtstag, Frankfurt am Main-Berlin-Bern-New York-Paris-Wien, 373-385.

15 Cf. el ya citado S. Döpp 1968, sobre la huella de Virgilio en Ovidio. En lo referente al posible papel de intermediario de las Hécubas de Enio y Acio, del Alejandro de Enio y de la Iliona de Pacuvio, cf. P. Venini 1952: 364-367, G. D’Anna 1959: 217234, J.P. Néraudau 1981: 35-51 y F. Bömer 1982: 308-309. Sobre el motivo de la tristeza en este pasaje, cf. C. HollenburgerRusch 2001: 33-34 y 106-119. 
R. M $M^{a}$ Iglesias-Ma C. Álvarez (2004), "La "Eneida" homérica de Ovidio", en T. Amado et alii (eds.), Iucundi acti labores. Estudios en homenaje a Dulce Estefanía Álvarez, Santiago de Compostela, 309-318.

R. M M Iglesias-M $^{\mathrm{a}}$ C. Álvarez (2005), "Ovidio, un poeta lascivus no tan lascivo", en R. Escavy et alii (eds.), Amica verba. Homenaje al profesor Dr. D. Antonio Roldán Pérez, Murcia, 403419.

F.W. Lenz (1967), "Betrachtungen zu einer neuen Untersuchung über die Struktur und Einheit der Metamorphosen Ovids", Helikon 7, 493-506.

W. Ludwig (1965), Struktur und Einheit der Metamorphosen Ovids, Berlin.

J.P. Néraudau (1981), "La métamorphose d' Hécube (Ovide, Métamorphoses, XIII, 538-575)", BAGB, $35-51$.

P. Venini (1952), "L'Hecuba di Euripide e Ovidio. Met. XIII 429-575", RIL 85, 364-367. 


\section{Série}

\section{Documentos}

Imprensa da Universidade de Coimbra

Coimbra University Press

2011

- $\mathrm{U}$

C • 